\title{
Late onset sepsis and intestinal bacterial colonization in very low birth weight infants receiving long-term parenteral nutrition
}

\author{
Sepse de ataque tardio e colonização bacteriana intestinal em neonatos de muito baixo peso \\ recebendo nutrição parenteral total
}

\author{
Priscila Castro Cordeiro Fernandes ${ }^{1}$, Elias Jose Oliveira von Dolinger ${ }^{1}$, Vânia Olivetti Steffen Abdallah ${ }^{1}$, \\ Daiane Silva Resende, Paulo Pinto Gontijo Filho ${ }^{2}$ and Denise von Dolinger de Brito ${ }^{2}$
}

\begin{abstract}
Introduction: The purpose of this study was to establish the late onset sepsis (LOS) rate of our service, characterize the intestinal microbiota and evaluate a possible association between gut flora and sepsis in surgical infants who were receiving parenteral nutrition (PN). Methods: Surveillance cultures of the gut were taken at the start of PN and thereafter once a week. Specimens for blood culture were collected based on clinical criteria established by the medical staff. The central venous catheter (CVC) tip was removed under aseptic conditions. Standard laboratory methods were used to identify the microorganisms that grew on cultures of gut, blood and CVC tip. Results: 74 very low birth weight infants were analyzed. All the infants were receiving PN and antibiotics when the gut culture was started. In total, 21 (28.4\%) infants experienced 28 episodes of LOS with no identified source. Coagulase negative staphylococci were the most common bacteria identified, both in the intestine (74.2\%) and blood (67.8\%). All infections occurred in patients who received PN through a central venous catheter. Six infants experienced episodes of microbial translocation. Conclusions: In this study, LOS was the most frequent episode in neonates receiving parenteral nutrition who had been submitted to surgery; $28.6 \%$ of this infection was probably a gut-derived phenomenon and requires novel strategies for prevention.
\end{abstract}

Keywords: Infants. Intestinal bacterial colonization. Late onset sepsis. Very low birth weight.

\section{RESUMO}

Introdução: O objetivo deste estudo foi estabelecer a taxa de sepse de ataque tardio (LOS) do nosso serviço, caracterizar a microbiota intestinal e avaliar uma possível associação entre a flora intestinal e sepse em recém-nascidos cirúrgicos que estavam recebendo nutrição parenteral (NP). Métodos: Culturas do intestino foram colhidas no início da nutrição parenteral e, posteriormente, uma vez por semana. As amostras para a cultura de sangue foram coletadas com base em critérios clínicos estabelecidos pela equipe médica. A ponta do cateter venoso central (CVC) foi removida sob condições assépticas. Métodos laboratoriais padrão foram usados para identificar os microrganismos que cresceram em culturas de sangue, do intestino, e da ponta do CVC. Resultados: Foram analisados 74 recém-nascidos de muito baixo peso. Todas as crianças estavam recebendo nutrição parenteral e antibióticos quando a cultura do intestino foi iniciada. No total, $21(28,4 \%)$ crianças apresentaram 28 episódios de sepse tardia sem fonte identificada. Os estafilococos coagulase negativo foram os mais comuns das bactérias identificadas, tanto no intestino $(74,2 \%)$ como no sangue $(67,8 \%)$. Todas as infecções ocorreram em pacientes que receberam nutrição parenteral através de um cateter venoso central. Seis crianças experimentaram episódios de translocação microbiana. Conclusões: Neste estudo LOS foi o episódio mais frequente em recém-nascidos recebendo nutrição parenteral e submetidos a cirurgia, $28,6 \%$ da infecção provavelmente foi um fenômeno derivado do intestino o que exige novas estratégias para a prevenção.

Palavras-chaves: Neonatos. Colonização bacteriana intestinal. Sepse tardia. Muito baixo peso.

1. Faculdade de Medicina, Universidade Federal de Uberlândia, Uberlândia, MG. 2. Instituto de Ciências Biomédicas, Universidade Federal de Uberlândia, Uberlândia, MG.

Address to: Dra Denise von Dolinger de Brito. Rua Pará 1720, Umuarama, 38400-902 Uberlândia, MG, Brasil.

Phone: 5534 3218-2236

e-mail: denisebrito@terra.com.br

Received in 21/12/2010

Accepted in 17/02/2011

\section{INTRODUCTION}

Advances in neonatal intensive care have improved survival among very low birthweight (VLBW) infants, but healthcare-associated infections remain an important cause of morbidity and mortality in this high-risk population ${ }^{1}$.

Late onset sepsis (LOS) is a common complication of prolonged admission to the neonatal intensive care unit (NICU) following preterm birth. LOS occurs after the third day of life and, among premature infants, it is most often caused by Grampositive organisms ${ }^{2}$.

The concept that potentially pathogenic intestinal microorganisms pass from the gut lumen into normally sterile tissue and cause systemic disease, including septicemia, in the absence of an anatomic alteration in the intestinal architecture is not a novel idea ${ }^{3}$.

Bacterial colonization of the intestine normally starts at birth as the infant encounters the environmental microflora. The preterm infant is exposed to the nosocomial flora in the neonatal intensive care unit (NICU) and is often treated with broad-spectrum antibiotics. It is likely that these circumstances affect the bacterial colonization of the intestine. The early colonization is influenced by factors, such as antibiotic treatment, feeding, mode of delivery and gestational age ${ }^{4}$.

Patients requiring parenteral nutrition $(\mathrm{PN})$ are at risk of infection. Studies suggest that septicemia in patients receiving $\mathrm{PN}$ may be primarily due to gut-derived microorganisms rather than external contamination of the intravenous catheter ${ }^{3,5}$.

The aims of this study were establish the LOS rate of our service, characterize the presence of intestinal pathogenic microbiota in the same cohort during the first 4 weeks of life and evaluate a possible association between gut flora and sepsis in infants who were submitted to surgery and were receiving parenteral nutrition. 


\section{METHODS}

\section{Setting and design}

Data were collected through the National Healthcare Safety Network surveillance system to evaluate the nosocomial infection and LOS rates. Between January and December 2009, 74 VLBW infants who were receiving PN were recruited from the NICU at Uberlândia University Hospital. The NICU consists of 2 rooms with a capacity of 15 infants and also serves as a referral center for several hospitals in the vicinity. Inclusion criteria were: I) birth weight $\leq 1500 \mathrm{~g}$; II) postnatal age $\leq 1$ week at admission and III) length of stay in the NICU $>1$ week.

An indication for PN was gut dysfunction due to the following types of congenital or acquired gastrointestinal anomalies: congenital intestinal obstruction, gastroschisis or omphalocele, prematurity or gut dysmotility, gastroesophageal reflux, congenital diaphragmatic hernia. Infants were administered PN through a central venous line. Enteral feedings were introduced gradually when gut motility recovered.

\section{Definitions}

\section{Microbial carriage}

Microbial carriage was considered to be present when the same strain of a microorganism, at any concentration, was isolated from a minimum of two consecutive surveillance samples over a period of at least one week ${ }^{6}$.

\section{Microbial translocation}

Microbial translocation was diagnosed if the microorganisms isolated from the blood culture, of infants who had been submitted to surgery and were receiving $\mathrm{PN}$, were indistinguishable from those carried in the rectum in the two weeks preceding the episode of septicemia ${ }^{3}$.

\section{Late onset sepsis}

LOS was determined by isolation of recognized pathogens from blood culture obtained after $72 \mathrm{~h}$ of life, which were not related to infection at anothersite, with $>38^{\circ} \mathrm{C}$ fever and with clinical signs of sepsis including apnea, temperature instability, lethargy, feeding intolerance, worsening respiratory distress or hemodynamic instability ${ }^{2,7}$.

\section{Central venous catheter related bloodstream infection}

CVC-related infection consists of the presence of clinical signs for sepsis, positive hemoculture with the same microorganism present on the catheter tip (by quantitative culture) and clinical and microbiological absence of any other source of infection ${ }^{8}$.

\section{Microbiological methods}

Surveillance cultures of the gut were obtained at the start of PN and thereafter, once a week. They were processed in a semiquantitative method, i.e., the four-quadrant technique combined with enrichment broth $^{6}$. The swabs were inoculated onto four solid media (Salt Manitol agar, Yeast agar, MacConkey agar and Blood agar plates) and placed into $5 \mathrm{~mL}$ brain-heart infusion broth. Growth density was classified as very low (equivalent to $<10 \mathrm{cfu} / \mathrm{mL}$ ) where only the enrichment broth was positive, low (equivalent to $10-10^{3} \mathrm{cfu} / \mathrm{mL}$ ), high (equivalent to $10^{6}-10^{7} \mathrm{cfu} / \mathrm{mL}$ ) and very high (equivalent to $>10^{7} \mathrm{cfu} / \mathrm{mL}$ ) where the plate had grown completely.
Blood cultures were collected based on clinical criteria including: apnea, bradycardia, temperature instability, feed intolerance, increased oxygen requirement, fever and lethargy. To avoid contamination of blood cultures, a specialized nurse drew blood after meticulous skin cleaning. Blood was processed using the BACTEC 9240 (Becton and Dickinson, Diagnostic Instrument Systems, Sparks, MD, USA) method.

\section{Central venous catheter (CVC) tip}

Catheters were removed when they were no longer required for patient care, when the patient experienced an adverse event, or when catheter exchange was necessary. Catheters were removed under aseptic conditions; their tips were cut off with sterile scissors and transferred in sterile tubes to the Microbiology Laboratory. A quantitative culture was performed, in accordance the techniques described by Brun-Buisson et $\mathrm{al}^{9}$, and was considered positive when $\geq 10^{3} \mathrm{cfu} / \mathrm{mL}$ were present.

Standard laboratory methods were used to identify the microorganisms that grew on cultures of gut, blood and CVC tip ${ }^{10}$. Sensitivity patterns were determined using the Clinical Laboratory Standard Institute method ${ }^{11}$. Nine antimicrobial agents were tested; oxacillin, cefotaxime, gentamicin, tetracycline, vancomycin, aztreonam, imipenem, cefepime and ciprofloxacin.

\section{Statistical analysis}

Repeated measures analysis was used to study crude variations in bacterial counts over time. Postnatal age in integer weeks was used for this analysis. When Mauchly's test of sphericity was significant, the Greenhouse-Geisser correction was applied.

\section{Ethics considerations}

This study was approved by the institutional research ethics committee and was conducted in accordance with the ethical standards of the committee responsible for human experimentation and with the Helsinki Declaration of 1975, as revised in 1983.

\section{RESULTS}

During the study period, 93 VLBW infants were evaluated; however, gut cultures were possible in only 74 , due to NUCI admission of less than $72 \mathrm{~h}$, death or extreme risk newborns with severe abdominal disease.

Their median gestational age was 32 weeks (range 25-40 weeks), median birth weight was $1.1 \mathrm{~kg}$ (range $0.70-1.5 \mathrm{~kg}$ ), median age at the start of $\mathrm{PN}$ was 3 days (range 1-45 days) and median duration of PN was 25 days (range 2-368 days).

Microorganisms identified at different postnatal ages are presented in Table 1. All the infants were administered PN and antibiotics when cultures of the gut were initiated. Coagulase negative staphylococci (CoNS) were the most $(74.2 \%)$ common bacteria identified. In all the cultures tested, an overgrowth of low level pathogens (e.g. CoNS) and potentially pathogenic microorganisms (Escherichia coli, Klebsiella pneumoniae, Enterobacter spp. and Serratia marscecens) were verified in the intestinal microflora of preterm infants, especially when receiving $\mathrm{PN}$. Using repeated measures analysis, a significant time effect was observed for CoNS, with an increase in bacterial count from weeks 0 to 2 ( $p<0.001)$, but not for Gram-negative bacteria $(\mathrm{p}=0.372)$. About $68 \%$ of infants received their own mother's breast milk from the third week of life, contributing to the reduction of pathogenic bacteria. About 
TABLE 1 - Intestinal bacterial colonization at different postnatal ages.

\begin{tabular}{|c|c|c|c|c|c|c|c|c|c|c|}
\hline \multirow[b]{2}{*}{ Microorganisms } & \multicolumn{2}{|c|}{ Days (3) } & \multicolumn{2}{|c|}{ Week (1) } & \multicolumn{2}{|c|}{ Weeks (2) } & \multicolumn{2}{|c|}{ Weeks (3) } & \multicolumn{2}{|c|}{ Weeks (4) } \\
\hline & $\mathrm{n}$ & $\%$ & $\mathrm{n}$ & $\%$ & $\mathrm{n}$ & $\%$ & $\mathrm{n}$ & $\%$ & $\mathrm{n}$ & $\%$ \\
\hline Staphylococcus saprophyticus $(\mathrm{n}=29)$ & 9 & 31.0 & 7 & 24.0 & 7 & 24.0 & 5 & 17.2 & 1 & 3.5 \\
\hline Staphylococcus epidermidis $(\mathrm{n}=20)$ & 12 & 60.0 & 6 & 30.0 & 2 & 10.0 & - & - & - & - \\
\hline Staphylococcus haemolyticus $(\mathrm{n}=13)$ & 6 & 46.2 & 4 & 30.8 & 2 & 15.4 & 1 & 7.6 & - & - \\
\hline Staphylococcus lugdunensis $(\mathrm{n}=7)$ & 4 & 57.1 & 3 & 42.9 & - & - & - & - & - & - \\
\hline Escherichia coli $(\mathrm{n}=8)$ & 1 & 12.5 & 4 & 50.0 & 2 & 25.0 & 1 & 12.5 & - & - \\
\hline Klebsiella pneumoniae $(\mathrm{n}=6)$ & 2 & 33.3 & 1 & 16.7 & - & - & 3 & 50.0 & - & - \\
\hline Enterobacter aerogenes $(\mathrm{n}=6)$ & 2 & 33.2 & 1 & 16.7 & - & - & 1 & 16.7 & 2 & 33.4 \\
\hline Enterobacter cloacae $(\mathrm{n}=3)$ & - & - & & & 1 & 33.3 & 1 & 33.3 & 1 & 33.3 \\
\hline Serratia marscecens $(\mathrm{n}=1)$ & 1 & 100.0 & - & - & - & - & - & - & - & - \\
\hline
\end{tabular}

$65 \%$ of infants were administered antibiotics (ampicillin and gentamicin) during the first two weeks and $20 \%$ used antibiotics (ampicillin, gentamicin, oxacillin and cefotaxime) during the entire hospitalization period.

In total, $30(40.5 \%)$ infants developed nosocomial infection and of these, 21 (26.9\%) infants experienced 28 episodes of late onset sepsis (Table 2) with no identified source. All infections occurred in patients who received $\mathrm{PN}$ through a central venous catheter. Thirteen episodes were considered catheter-related sepsis. Only three of these patients received PN for less than two weeks. More than half of all septicemic episodes were due to CoNS. Among the 19 CoNS (67.8), S. epidermidis (73.7\%) was the predominant isolate, followed by $S$. haemolyticus (15.7\%), S. lugdunensis (5.3\%) and S. agalactiae (5.3\%).

Of the 21 infants with sepsis of unidentified source, six drew should be highlighted. All six were considered catheter-related sepsis; all were caused by CoNS (Table 3). These neonates were being administered PN and antibiotics and were submitted to surgical procedures because of a gastroschisis (four) and congenital intestinal obstruction (two) had indistinguishable strains of CoNS in the rectum, including the antimicrobial susceptibility profile, meeting our definition of microbial translocation.

All the strains isolated in this study were tested for antimicrobial susceptibility. In isolates of the blood $(45.8 \%, 11 / 24)$ and the

TABLE 2 - Microorganisms isolated from 28 septicemic episodes in 21 patients.

\begin{tabular}{lccc}
\hline & Patients $(\mathbf{n}=\mathbf{2 1})$ & \multicolumn{2}{c}{ Episodes $\left(\mathbf{n}=\mathbf{2 8} \mathbf{*}^{*}\right)$} \\
\cline { 3 - 5 } Microorganisms & $\mathrm{n}$ & $\mathrm{n}$ & $\%$ \\
\hline Coagulase negative staphylococci & 14 & 19 & 67.8 \\
\hline Staphylococcus aureus & 4 & 5 & 17.9 \\
\hline Enterococcus faecalis & 1 & 2 & 7.1 \\
\hline Enterobacter cloacae & 1 & 1 & 3.6 \\
\hline Candida sp. & 1 & 1 & 3.6 \\
\hline
\end{tabular}

${ }^{*}$ Four patients had more than one episode and three episodes were polymicrobial.

TABLE 3 - Episodes of catheter-related sepsis suggesting microbial translocation in infants receiving parenteral nutrition.

\begin{tabular}{llll}
\hline Infant & Hemoculture & CVC tip & Intestinal microbiota \\
\hline 1 & S. epidermidis & S. epidermidis & S. epidermidis \\
\hline 2 & S. epidermidis & S. epidermidis & S. epidermidis \\
\hline 3 & S. epidermidis & S. epidermidis & S. epidermidis \\
\hline 4 & S. epidermidis & S. epidermidis & S. epidermidis \\
\hline 5 & S. lugdunensis & S. lugdunensis & S. lugdunensis \\
\hline 6 & S. haemolyticus & S. haemolyticus & S. haemolyticus \\
\hline
\end{tabular}

CVC: central venous catheter, S: Staphylococcus. intestine (100\%), staphylococci demonstrated a high frequency of multidrug resistance to the antimicrobial agents tested. The other microorganisms were susceptible.

\section{DISCUSSION}

The intestinal microbiota of 74 VLBW neonates was studied during the first 4 weeks of life. In agreement with previous studies of preterm infants ${ }^{12}$, this study showed early, predominant colonization with potentially pathogenic bacteria. A recent study showed that the prolonged period prior to full enteral feeding could explain this finding ${ }^{13}$.

Early introduction of enteral feedings is thought to stimulate the intestine of preterm infants. This should maximize the immune functions of the intestine, reduce the risk of infection and improve the outcome of preterm infants ${ }^{14}$. In the present study, this was only possible from the third week of life due to the degree of ill health of the newborns.

Among the agents of infectious diseases in neonates, CoNS, especially Staphylococcus epidermidis, are emphasized as being predominantly of endemic nature ${ }^{15}$. Furthermore, they are the main cause of LOS in Neonatal Intensive Care Units (NICUs), in relation to neonates of low weight, and are often implied in outbreaks, with significant increase in morbidity, mortality, length of admission and cost. In this series, sepsis (69.2\%) was the most frequent episode in neonates, with CoNS accounting for $67.8 \%$ of cases. These results are consistent with those published by Smith et $\mathrm{al}^{16}$, where the incidence of septicemia was almost $60 \%$. The predominant microorganisms (49\%) were the low-level pathogens, CoNS and enterococci.

A total of 21 neonates presented with sepsis of an unidentified source, six $(28.6 \%)$ had septicemia due to translocation were administered $\mathrm{PN}$ and antibiotics and had been submitted to surgical procedures. In all cases, prior to the onset of the disease, a high count of indistinguishable strains of CoNS was verified in the rectum. Minimal data are available regarding intestinal translocation ${ }^{3,5}$. This is probably due to the difficulty in proving bacterial translocation from the intestine into the bloodstream. Unlike that was observed in this study, microbial translocation was responsible for $84 \%$ of septicemic episodes in the study by O'Donnell et $\mathrm{al}^{5}$.

Consistent with previous studies from NICUs ${ }^{17,18}$, a high overall level of antibiotic resistance was verified among the staphylococci isolates in this study, representing $45.8 \%$ of infection episodes and intestine isolates (100\%), which is indicative of increased transmission rates of these bacteria and simultaneously high 
antimicrobial usage, particularly oxacillin, cephalosporins and/ or aminoglycosides. Different explanations for this observation may exist. These neonates were premature, received more invasive procedures, such as CVC, and were more frequently exposed to prophylactic antibiotics, which in turn may lead to the selection of resistant microbes ${ }^{19}$.

In conclusion, in this study, LOS was the most frequent episode in neonates receiving parenteral nutrition who had been submitted to surgery; $28.6 \%$ of this infection was a gut-derived phenomenon and requires novel strategies for prevention.

\section{ACKNOWLEDGMENTS}

The authors would like to thank the neonatal nursing staff for their generous assistance during this study.

\section{CONFLICT OF INTEREST}

The authors declare that there is no conflict of interest.

\section{FINANCIAL SUPPORT}

\section{FAPEMIG.}

\section{REFERENCES}

1. Geffers C, BaerwolffS, Schwab F, Gastmeier P. Incidence of healthcare-associated infections in high-risk neonates: results from the German surveillance system for very-low-birthweight infants. J Hosp Infect 2008; 68:214-221.

2. Stoll BJ, Hansen N, Fanaroff AA, Wright LL, Carlo WA, Ehrenkranz RA, et al. Late-onset sepsis in very low birth weight neonates: the experience of the NICHD Neonatal Research Network. Paediatrics 2002; 110:285-291.

3. Pierro A, van Saene HKF, Donnell SC, Hughes J, Ewan C, Nunn AJ, et al. Microbial translocation in neonates and infants receiving long-term parenteral nutrition. Arch Surg 1996; 131:176-179.

4. Campeotto F, Waligora-Dupriet AJ, Doucet-Populaire F, Kalach N, Dupont C, Butel MJ. Establishment of the intestinal microflora in neonates. Gastroenterol Clin Biol 2007; 31:533-542.

5. Donnell SC, Taylor N, van Saene HKF, Magnall VL, Pierro A, Lloyd DA. Infection rates in surgical neonates and infants receiving parenteral nutrition: a five-year prospective study. J Hosp Infect 2002; 52:273-280.

6. van Saene HKF, Damjanovic V, Murray AE, de la Cal MA. How to classify infections in intensive care units. The carrier state, a criterion whose time has come? J Hosp Infect 1996; 33:1-12.

7. Butler-O’Hara M, Buzzard CJ, Reubens L, McDermott MP, Di Grazio W, D’Angio $\mathrm{CT}$, et al. A randomized trial comparing long-term and short-term use of umbilical venous catheters in premature infants with birth weights of less than 1251 grams. Paediatrics 2006; 19:25-35.

8. Öncü S, Özsüt H, Yildirim A, Pinar A, Cakar N, Eraksoy H, et al. Central venous catheter related infections: risk factors and the effect of glycopeptides antibiotics. Ann Clin Microbiol Antimicrob 2003; 2:1-6.

9. Brun-Buisson C, Abrouk F, Legrand P, Huet Y, Larabi S, Rapin M, et al. Diagnosis of Central Venous Catheter-related sepsis. Critical level of quantitative tip cultures. Arch Intern Med 1987; 147:873-877.

10. Lennette E, Balows A, Hausler W, Shadomy H. Manual of Clinical Microbiology. $3^{\text {rd }}$ ed. Washington DC: American society for Microbiology; 1980.

11. Clinical and Laboratory Standards Institute. Methods for dilution antimicrobial susceptibility tests for bacteria that grow aerobically. Approved Standard M7-A5. $5^{\text {th }}$ ed. Wayne, Pensylvania: Clinical and Laboratory Standards Institute; 2006.

12. Björkström MV, Hall L, Söderlund S, Hakansson G, Hakansson S, Domellof M. Intestinal flora in very low-birth weight infants. Acta Paediatrica 2009; 98:1762-1767.
13. Picaud JC. Formula-fed preterm neonates. Minerva Pediatr 2003; 55:217-229.

14. Westerbeek EAM, Berg AVDB, Lafeber HN, Knol J, Fetter WPF, Elburg RMV. The intestinal bacterial colonization in preterm infants: a review of the intestinal. Clin Nutrition 2006; 25:361-368.

15. Brito DVD, von Dolinger EJ, Abdallah VO, Darini AL, Gontijo Filho PP. Two outbreaks of mixed etiology associated with central venous catheters inserted by phlebotomy in critical neonates. Braz J Infect Dis 2009;13:177-182.

16. Smith MJ. Catheter-related bloodstream infections in children. Am J Infect Control 2008; 36:s173.

17. Sakaki H, Nishioka M, Kanda K, Takahashi Y. An investigation of the risk factors for infection with methicillin-resistant Staphylococcus aureus among patients in a neonatal intensive care unit. Am J Infect Control 2009; 37:580-586.

18. van den Hoogen A, Gerards LJ, Verboon-Maciolek MA, Fleer A, Krediet TG. Long-term trends in the epidemiology of neonatal sepsis and antibiotic susceptibility of causative agents. Neonatology 2010; 97:22-28.

19. Amaya E, Caceres M, Fanc H, Torres Ramirez A, Palmgren AC, Nord CE, et al. Antibiotic resistance patterns in gram-negative and gram-positive bacteria causing septicemia in newborns in León, Nicaragua: correlation with environmental samples. J Chemother 2010; 22:25-29. 